\title{
AUSTRALIAN FOLKLORE YESTERDAY AND TODAY: DEFINITIONS AND PRACTICES
}

\section{J. S. Ryan}

In 1993 there was published a milestone volume, The Oxford Companion to Australian Folklore, edited by Graham Seal and Gwenda Bede Davey. This influential compendium had followed hard upon: the first issue of Australian Folklore: A Yearly Journal of Folklore Studies, edited by Graham Seal and David S. Hults, in $1987 ;{ }^{1}$ the various biennial folklore conferences ${ }^{2}$ of the Australian Folk Trust; and the appearance of Graham Seal's The Hidden Culture: Folklore in Australian Society (1989; re-issued in 1993). This publicaton was the first attempt to provide a textbook in Australian folklore, and the first full-length analytical volume on Australian folklore as a whole. For June Factor's earlier and deservedly famous study Captain Cook Chased a Chook (1988), had confined its analysis to children's folklore in Australia. G. Seal has argued that folklore is best understood as a historical continuum, a continuing and infinitely flexible tradition in which the forms may change but the process remains the same.

Meanwhile, on 26 March 1986, the then Minister for Arts, Heritage and Environment had announced the establishment of the Committee of Inquiry into Folklife in Australia. The minister appointed to the committee HughAnderson (folk publisher and scholar of ballads); Gwenda Davey (folklorist of early childhood and lecturer on folklore); and Keith McKenry (folk musician and folk poet). This world-travelling and consulting group tabled its report, Folklife: Our Living Heritage on 14 August 1987, covering the designated tasks of surveying in some depth:

1. The nature, diversity and significance of Australian folklife.

2. Existing (institutional) arrangements for safeguarding that folklife and the need for new arrangements for (a) collection, documentation and dissemination of folklife materials; (b) support/development of folk arts, etc. 
It had agreed not to report on traditional Aboriginal ceremonial and belief but to address such other aspects of Aboriginal folklife as: craft, contemporary folklife, both urban and rural; and the present intertwining of Aboriginal folklife with that of other communities within Australian society.

This report preferred term 'Folklife', which related 'more directly to living culture' as its main designation of the field, following recent American and UNESCO practice, and argued that folklore/ folklife - the terms were used inter-changeably - ... performs many important social functions related to group identity, release of cultural tensions and ambivalences, entertainment and eduction (Folklife 1987: 65).

It also produced its own definition of folklife: Folklife is a tradition-based and/or contemporary expressive culture repeated and shared within a community, and accepted as an adequate reflection of its cultural and social identity. It embraces a wide range of creative and symbolic forms such as custom, belief, mythology, legend, ritual, pageantry, language, literature, technical skill, play, music, dance, song, drama, narrative, architecture, craft. Its expressions are mainly learned orally, by imitation or in performance, and are generally maintained without benefit of formal instruction or institutional direction.

The Committee rejected the hitherto prevailing Anglo-Celtic tradition as the sole focus (Folklife 1987: 140, 170, etc.) and expressed positive interest in all immigrant materials, however difficult of collection.

The document was to some degree at the mercy of the input groups, more than 150 in all. This makes the un-indexed text hard to read as it endeavours to specify the needs of such areas as dance, music, bushcrafts, musical instrument making, song writing, union/street theatre, National Trusts, Ethnic Community Committees, Museums of many kinds, $\left(\right.$ State $\left.^{4}\right)$ Libraries, or such distinctive activities as the Tamworth Country Music Festival (Folklife 1987: 41).

While this compilation has been largely ignored in the political and funding areas, it has much to offer students of music, dance, or manual crafts, and to those associated with regional museums. For 
its enduring importance lies in its honest and generous analysis of the contemporary 'folklife' scene. It has already done much to nurture the 'folkways' which make up both our personal and national sense of identity and understanding of customary lifestyles.

Folklife: Our Living Heritage may be taken into consideration together with its almost exact contemporary the other important investigation Windows Onto Worlds. Its pivotal perception was that Australians want their education to give them a firmer and sharper sense of their own place and culture (Windows 1987: ix).

In its chapter on 'Humanities' there was much stress on the need for more Australian studies in the disciplines of history and literature, while in the section (Windows 1987: 195, ff.) on Heritage and Cultural Resources there is repeated the charge that traditional educationalists were neglecting areas of popular interest, leading to claims that 'new disciplines' be established:

For instance, a wealth of material for Australian studies has been collected and conserved for many years by individual folklorists and folk societies. Folklorists claim that this material, which offers extensive and unique insights into ways of living in Australia, has been ignored by traditional scholars and by collecting agencies ... Folklore studies have been developed in part because established disciplines have not responded to the ways in which the community has looked at itself. Scope exists within anthropology, history and literature departments to use folklore material more fully than was done in the past. (Windows 1987: 201-202)

It is to be noted that Australia had input into and has sought actively to endorse the definition adopted by the UNESCO Second Committee of Governmental Experts on the Safeguarding of Folklore meeting in Paris in 1985:

Folklore (in a broader sense, traditional and popular folk culture) is a group-oriented and tradition-based creation of groups or individuals reflecting the expectations of the community as an adequate expression of its cultural and social identity; its standards and values are transmitted orally, by imitation or by other means. Its forms include, among others, language, litera- 
ture, music, dance, games, mythology, rituals, customs, handicrafts, architecture and other arts.

This same definition was used by the Committee of Inquiry into Folklife in Australia. Still, they modified it to exclude 'tradition based' and they excluded literature as a form of folklore. This decision tended to put university-type institutions on one side of the folklore continuum and museums and heritage centres on the other. However, this seeming dichotomy was reversed with the July 1989 inclusion of all tertiary education into the Unified National System.

Of course, this Australian tale of struggle and slow regrowth well seem quaint in the Baltic, Scandinavian, Celtic and (North) American countries ${ }^{5}$ where the battle was won long ago, but, in Australian universities folklore is still a newcomer. Formal instruction at the course-work stage is offered only in Curtin University of Technology (the 1980s), antecedent institutions of the University of South Australia in the $1980 \mathrm{~s}^{6}$, Colleges of Advanced Education (in New South Wales; the 1980s), Monash University (the 1990s), and the University of New England (in New South Wales; 1998)7.

B. ('Banjo') Patterson actively solicited folk ballads for the anthology Old Bush Songs (1905), seeking to capture one aspect of the passing and endangered life-style of gold-miners, 'overlanders' (i.e. droving cattle) and shearers. His efforts were continued in the $1950 \mathrm{~s}$ busy collecting activities and analyses that would focus almost entirely on 'bush life, and on its songs, music and dance. Equally important was the analysis of the yarn, as in the classic volume The Australian Yarn by Ron Edwards (1977) ${ }^{8}$.

Thus it may be argued that there have been three periods of activity and scholarly endeavour since the white settlement which began in 1788:

I the urgency of the Federation time (1901), when the various separate states came together to form the Australian nation, and a 
feeling then that the pastoral/bush age was passing, with the focus then on the urban life-style;

II the period c. 1945-1960, with the emphasis on collecting of folk song and music and the oral performance of this song and like material, largely outside tertiary educational institutions. This emphasis was probably due to a suspicion that their treatment there would separate folklorists from their sources. In this period, folklore was often equated in the community - indeed, as it still is - with legends, myths, or received knowledge of a collective consciousness, causing this 'folklore' to be largely associated with oral forms of transmission;

III the period from the mid-1980 $\mathrm{s}^{9}$ to the present. This period was much stimulated by preparation for theAustralian Bicentennial in 1988. Characteristic of this period is that imported mass culture has seemed to threaten/overwhelm folk or popular culture and that folklore has been extended as a concept to embrace much of folklife or traditional culture.

In the last quarter century or so the folk traditions of multicultural Australia have been explored and folklore developed to embrace material forms, such as: crafts like quilt- or whip-making; food ways; hybrid traditions of many complex forms; customs, beliefs and superstitions; urban legends $\mathrm{s}^{10}$; (political) gossip; memorates; oral history; and many other forms of joke, anecdote, graffiti, rumour, etc. which shed a wry light on our socio-cultural processes.

Indeed, we may well agree with Graham Seal's account of more recent folklore (i.e. tale, idiom, etc.) that, although seemingly (superficially?) localized in place and/or characters, and frequently sharply anti-authority, racist, sexist and scabrous, Its enormous popularity in Australia confirms the country's status as a typical polyethnic, overwhelmingly urban-dwelling, industrial/technological modern nation state (Seal 1994: 519).

It may also be noted that in Australia, as in many other countries, anthropology ${ }^{11}$ has been reappraising its position. It is endeavouring to assist the public's coping with 'a social world which has 
changed almost out of recognition in a few short years', and becoming more focused on its own country. Anthropology today is concerned to 'conserve the spice of marginality' as well as to study tourism, nostalgia, organizational rituals, and many other 'internal' manifestations of the home culture.

Dr. Jacqueline Simpson has argued that, during the period of her editorship in 1968 to 1992, the international journal Australian Folklore had been concerned to represent meaningfully

a steady broadening of the subject, a growing preference for precise documentation ... a more realistic appraisal of historic and social factors, a greater diversity both of the genres and of the social groups studied ... [and] an equally strong concern with the present (Simpson 1994: 16).

The present writer (Ryan 1995) has argued that the now substantial annual Australian volume endeavours to reflect the widely recognised diversity of discipline, ... endeavouring to cultivate links with other disciplines, and not to commit itself to propagating any one school of thought, simplistic definition of the field or arbitrarily limited time period ... especially as

the whole dynamic of the past re-asserts itself as a new re-experiencing of the past in the new found vitality of ethnic, racial and nationalistic developments in the folk cultures that they drive and motivate (Browne \& Ambrose 1993).

In keeping with these exhortations it may be noted that these 'new' matters amongst many others have been addressed in the last three years of the Australian journal.

\section{Comments}

${ }^{1}$ Since late 1991 the Journal has been edited by J. S. Ryan. From No. 7 (1992) the publication has become more representative of all Australia and much increased its international content and subscription base.

${ }^{2}$ The largest early conference of this sort was the Second National Folklore Conference, held in Sydney in 1986. Its very bulky pro- 
ceedings were issued in 1987 as The Possum Stirs, ed. Keith Hollinshead.

${ }^{3}$ Then at the University of Melbourne, she has more recently taught various graduate courses on Australian folklore at the National Centre for Australian Studies at Monash University, Clayton, Victoria. See Australian Folklore No. 12 (1997), p. 45 for details of the Monash Graduate Diploma in Australian Folklife Studies. That qualification has as its core these subjects: Australian Folk Culture: A Multilingual Perspective; Cultural Mapping and Oral History: Methodologies for Community Study; Popular and Vernacular Culture in Australia; Material Culture: Theory and Practice; Cultural tourism.

${ }^{4}$ Originally founded in the capitals of the several states before Federation in 1901, they are often still much stronger in the holdings of rare state books and papers than the National Library in the Federal Capital in Canberra.

${ }^{5}$ Compare the career of Stith Thompson as discussed in Australian Folklore No. 12 (1997), pp. 98-99.

${ }^{6}$ More specifically, the following courses: 'Australian Folk Tradition' - with a South Australian field research component; 'The Australian Ethos: AStudy Through Folklore and Literature' - predominantly literary studies, with oral sources.

${ }^{7}$ A undergraduate course for far distant students in the B.A., entitled 'Australian Folklore and Australian Folk Speech'.

${ }^{8}$ It was reprinted as a paperback in 1996.

${ }^{9}$ Influenced by US Public Law 94-201 which invoked the American Folklore Preservation Act in 1976.

${ }^{10}$ While many contemporary legends heard/collected here are clearly variations of stories circulating in many lands, there is one which is uniquely Australian - W. N. ('Bill') Scott's tale of the pelican kidnapping (swallowing?) a chihuahua dog. See his 'An Australian Contemporary Legend?' Australian Folklore No. 11 (1995), pp. 213218. 
${ }^{11}$ See the review-discussion by the present author ofAkbar S.Ahmed and Cris Shore (eds.) The Future of Anthropology (1995) in Australian Folklore No. 12 (1997), pp. 112, ff.

\section{References}

Browne, Ray B. \& Ambrosetti, Ronald J. 1993. Continuities in Popular Culture: The Present in the Past and the Past in the Present and Future. Bowling Green, Ohio, p. 1.

Folklife: Our Living Heritage 1987. Canberra.

Ryan, J. S. 1995. Editorial. Australian Folklore. Perth.

Seal, Graham 1994. 'Folklore (Australia)'. E. Benson and L. W. Conolly (eds.). Encyclopedia of Post-Colonial Literatures in English. Vol. 1. London \& New York, p. 519.

Simpson, Jacqueline 1994. Folklore in Folklore: trends from 1968 to 1992. Simpson, J. \& Roud, S. (eds.) An Index to Folklore. Vol. 79103. London, pp. 9-16.

Windows Onto Worlds: Studying Australia at the Tertiary level. The Report of the Committee to review Australian studies in tertiary education. Canberra 1987. 